\title{
DEDICATION OF A TRI-STATE BOUNDARY MARKER
}

In 1859 the boundary line between the state of Minnesota and Dakota Territory was surveyed by Snow and Hutton from a point where this line intersects the northern boundary line of the state of Iowa. This point, about sixteen miles east and somewhat south of Sioux Falls, South Dakota, and about four miles north and west of the town of Larchwood, Iowa, was marked by an appropriate iron marker such as was used in the federal surveys to mark the corner of state boundaries. Locally the marker came to be known as the "Old Iron Post."

In later years the marker was badly damaged by vandals who apparently desired to cut pieces from it as souvenirs. Because the highways that crossed at the point where the marker stood were not graded, the roads did not drain, and travel along them was hazardous; eventually the place where the marker stood resembled a slough.

Some years ago the attention of the Minnehaha County (South Dakota) Historical Society was called to the damaged and neglected condition of this marker of the intersection of the boundary lines of Iowa, Minnesota, and South Dakota. Mr. Charles A. Smith, secretary of the Minnehaha County Historical Society felt that action was necessary. The story of the society's efforts to restore the marker is told in Mr. Smith's report quoted below:

Representatives of the society visited the place, found the post in a leaning position in the dirt road that crossed a low seetion of land and a hole about the size of a man's hand broken through the iron walls of the old marker. The matter was reported to the society, but because of the expense required to properly reset it and to grade the roads leading to it, which expense would fall heavily on the bordering townships, since a deep fill would be necessary to make the roads passable and the old corncr accessible, the matter was allowed to lag but was never entirely lost sight of.

In the early fall of 1937 an attempt was made to interest the Governors of the three states to meet on the listoric corner. Citizens of Rock County, Minnesota, were holding a celebration at Luverne, 
and certain public-spirited residents of that city sponsored the 'get together.' Because of the condition of the roads few of the people reached the place, and not one of the Governors was present. However, Governor Leslie Jensen of South Dakota did get to Luverne, but only two men, members of the Minnchaha County Historical Society, reached the spot after battling the mud for several miles. The small hole of a fow years before had become enlarged by souvenir hunters to more than two feet long and the full width of the pillar. These members reported the matter to the society with the determination that the landmark must be repaired and preserved.

How to get results was the problem of the group. The state govermments were appealed to with no tangible results. The Department of Interior at Washington disavowed any anthority in the mat. ter and added that 'furthermore there were no funds available for such a project.' The society then concentrated its efforts on the three bordering counties of three adjoining states. All three groups of County Commissioners and Supervisors were interested. Lyon County, lown, was the first to declare, 'We are ready and willing to do our share if the other two will cooperate.' Rock County, Minnesota, readily agreed to cooperate, and Minnehaha County, South Dakota, agreed to meet with the other two groups on the corner and asked the counties of Lyon and Rock to do so.

It was late in the fall, and the day set for the mecting was raw and cold, but every man of the three county boards was present, and with them were their respective highway superintendents and the County Auditor of Mimnchaha County. Though it was cold and windy, they all stayed there and throughly sized up the lay of the ground. At this point the Honorable J. B. Severson of Valley Springs Township invited the entire group, including a large delegation of the Historical Society, to go to his house for their deliberations, and this was done. Those who witnessed the procedure declared it was the most harmonious erent involving expenditures of money they had ever witnessed. The counties then and there agreed to divide up the work and that the work at the intersection of the highways should be equally divided as to payments.

In the cffort to interest these groups in the enterprise, the practical nature of it must necessarily be brought out, for these men, while sentimentally inclined to preserve the old landmarks their fathers had set, were spending public money, and it was rather a cold business matter with them. Here four mile of roads, euts, and fills, and gravel, must be regraded. Therefore the society must carry business and sentiment along together. It was learned that two mail routes served the public over the ill-kept roads, one along the Iowa-Minnesota border served by the Larchwood post office, and one along the MinnesotaSouth Dakota line. In the winter time these roads were utterly im- 
passable, and some of the patrons had to walk two miles to get their mail and often would not get it for days and even weeks at a time. The situation was deplorable, and the hardship on the farmers unjust and unnecessary. The same difficulty was encountered when trying to get to town to buy the necessitics of life and to market their produce.

This condition was not lost sight of in appealing to the respective county boards and to the Interior Department at Washington. The latter, it was found, did have some interest in the old marker after all. It could not be moved even for repairs. Honorable L. E. Larson of Colton, one of the county commissioners of Minnehaha County, about to go to Washington on a business trip was given credentials to get authority to make such repairs. He was as much at sea about where to start as the rest of the group but tackled the job. After being sent from place to place he was finally direeted to the General Land Office, where the desired authority was fortheoming.

It is hardly believable unless one tackles a job like this, that sueh a seemingly small matter should involve so much work, eorrespondence, contact, and so many trips to and from the place by auto. It required perseverance, but it was wortlı it to see the very unusual spectacle of three county boards in utmost harmony and good will practicing co. operation and fair play.

Great credit is due in this matter not only to $\mathrm{Mr}$. Smith and the Minmehaha County Historical Society, but to the boards of supervisors of Lyon County, Iowa, Rock County, Minnesota, and Minmehaha County, South Dakota, for at a joint meeting it was decided that the road on the boundary line between Minnesota and Iowa, and South Dakota and Iowa-an east and west road-should be graded, and that the road coming from the north on the boundary line between Minnesota and South Dakota should also be brought to this same grade at the point of intersection of the boundary lines of these states. It was a large job for the counties to undertake, but it was thoroughly done.

The general land office had been consulted and permission and other assistance was given to restore the marker and to reset it at its proper place. The marker is made of iron, is approximately six feet high, and a small area of ground immediately surrounding. it is enclosed by an iron fence imbedded in a heavy concrete foundation. Around this is an elliptical ring of concrete in the effort to prevent autoists from colliding with the marker. 
At the upper end of the monument appears the following legend: $43: 30 \mathrm{~N}$.. . This is the longitude west of Washington, D. C. On the west side of the monument is a bronze tablet on which is inscribed the following:

\author{
THIS MARKER \\ ERECTED IN 1849 \\ By the United States \\ GOVERNMENT \\ Marking Junction \\ IOWA MINNESOTA \\ Dakota Territory \\ Marker Damaged by Vandals \\ REPAIRFD AND RFSET \\ UNDER \\ DiRECTION OF \\ DFPARTMENT OF INTERIOR \\ $\mathrm{BY}$ \\ Lyon County, Iowa \\ Rock County, Minnesota \\ Minnehaha County, South Dakota
}

The monument was dedicated on Sunday, October 9, 1938. The interest aroused in the historic importance of this tristate marker was surprisingly great. It is estimated that a total attendance of 4,000 witnessed the dedication and listened to the exercises later in the park at Larchwood. It was not only a large crowd but an extremely friendly crowd. It was noted that while the citizens of three states gathered, they gathered as citizens of the United States of America who recognized that the problems common to one state were common to all three of them.

The curator participated in the program which follows:

\title{
TRI-STATE MARKER DEDICATION PROGRAM
}

Sunday, October 9, 1938

Program at Tri-State Marker 2 P.M.

Selections by Lureme, Minnesota Band

Invocation.

Rev. E. B. Woodruff, Dean of Calvary Cathedral, Sioux Falls 
Dedicatory Address

Selection by Hills, Minnesota Band

District Judge Julius E. Haycraft, Fairmont, Minnesota

President Martin County, Minnesota Historical Society, Member Board

Minnesota Fistorical Society

Program at Larchwood, Iowa, 2:45 P.M.

Selections by Sioux Falls IIigh School Band

Invocation

Remarks by Representatives of Roek County, Minnesota; Lyon County, Iowa; and Minnehaha County, South Dakota

State Representative Dykhouse representing Tyon County, Iowa

Hon. J. N. Jacobson representing Rock County, Minnesota

ILon. Martin Graff representing Minnehaha County, South Dakota

Remarks by Hon. L. E. Larson representing U. S. Department of Interior.

Selection by Rock Rapids Band

Addresses by Representatives of the states of Iowa, Minnesota and South Dakota:

District Judge Julius E. Haycraft, Member of Board of Minnesota Historical Society, representing the state of Minnesota

Hon. O. E. Klingaman, Curator Iowa Historical Society representing the state of Iowa

Hon. Donald McMurchie, Lt. Gov. of South Dakota representing the state of South Dakota

Selection by Rock Rapids Band

Remarks by Hon. Lawrence K. Fox, Secretary of South Dakota Historical Society

Remarks by Hon. A. N. Graff, Mayor of Sioux Falls, South Dakota

Selection by Rock Rapids Band 
Copyright of Annals of Iowa is the property of State of Iowa, by \& through the State Historical Society of Iowa and its content may not be copied or emailed to multiple sites or posted to a listserv without the copyright holder's express written permission. However, users may print, download, or email articles for individual use. 